\title{
Essential Elements of Security and their Applications in Ensuring Stability and Integration of Nigeria.
}

\author{
Ufot Akpan Phenson (Ph.D) in view ${ }^{1}$,Peter Abang Ojie (Ph.D) in view ${ }^{2}$, John O. \\ Esin (Ph.D) ${ }^{3}$, Anietie John Atai (Ph.D) in view ${ }^{4}$ \\ 1. Department of Political Science \& Public Administration, University of Uyo, Uyo, Akwa Ibom State, Nigeria. \\ 2. Department of Political Science \& Public Administration, University of Uyo, Uyo, Akwa Ibom State, Nigeria. \\ 3. Department of Geography/Natural Resources Management, University of Uyo, Uyo, Akwa Ibom State, \\ Nigeria \\ 4. Department of Political Science \& Public Administration University of Uyo, Uyo, Akwa Ibom State, Nigeria.
}

\begin{abstract}
This study attempts to $x$-ray the essential elements of security and the need for their application in ensuring the stability and integration of the Nigerian federation in the light of the fore-going heightened security challengesin Nigeria. No nation can freely develop or overcome the forces of instabilities and disintegration when it neglects the effectiveharnesment or applicationof basic or essential elements of security. Such critical elements of security include; timely procurement of security intelligence, prompt identification of threats to both internal and national security, with its attendant pro-active security arrangement, threat assessment, statement of aims/objectives of national security objectives and programmes, planning to be in line with the objectives of national security. Others are; security liaison, and net-working with other sister security departments towards achieving the national security objectives, effectively coordinating security and its activities under a centralized command structure, re-appraisal of the overall security objectives, situations and strategies in the light of new developments as well as advising government based on the situation on ground for the overall improvement of security measuresand adequate funding. In the case of Nigeria, security lapses and challenges manifest on daily basis in forms of youth restiveness, terrorism and insurgent attacks, kidnappings and hostage-takings for monetaryransoms, political assassinations, arsons, murders, cult-related activities, mass protests and so forth: theseare traceable to neglect of these essential elements of security.However, the past military leaders and political class in Nigeria, seem less interested toadequately fund security departments to enable them cope with security challenges in the country. They seem to pay lip-services to the critical elements of security until small internal disputes are allowed due to political partisan and ethnoreligioussentiments to snow-ball to security crises of national dimension as is the case with the present Boko Haram insurgencypresently threatening Nigeria's stability, unity and existence. This work analyzes descriptively while multi-track security model is the theoretical framework. This work indicates that the Nigerian Government which has the sole statutory mandate to manage state security has not effectively harnessed the critical essentials of security to achieve the stability and integration of the country. The work therefore recommends that the Nigerian leaders should holistically address and utilize the essential elements of security in ensuring the stability and integration of the Nigerian Federation by effectively organizing, planning, funding, controlling, directing and integrating technical elements with human, and material resources towards achieving the stability and integration of the Nigerian state.
\end{abstract}

Key Words: Essential Elements of Security, Security, Stability, Integration.

\section{Introduction}

Any nation that ignores importance of security to her developments is bound to face instabilities and threats to her corporate existence as in the case of Nigeria in recent times. The past governments both military and civilian have tended to pay lip-services to security asreflected in inadequate funding and equipping of these security departments especially, the Nigerian Police Force. As a result of the observed lack of prioritization of needs of these security providers in Nigeria, the country has continued to face destabilizing threats to her corporate existence and national integration. The lack of training and inadequate man-power observed amongst these poorly funded and badly motivated security forces, has continued to create man-power shortages needed to fight-off these security challenges particularly, in Nigerian police force where there is only 205 policemenprotecting 100,000 citizens as against the UNO or world's acceptable standards of 222 police per 100,000 citizen (UNO Report, 2012).

The multi-ethnic and cultural nature of Nigeria and the weak judicial institutions as well as politicization of security matters due to interferences by politicians have continued to force these security departments to compromise their statutory functions at the detriment of effective national security 
management.Prolongeddelays to response to threat indicators, creates aversion to and engenders adverse public image of these security forces and negatively affect public perceptions and relationship with these security forces. This makes the public reluctant to divulge critical security information to them at the detriment of effective management of national security matters.

The over-bearing influences of tribal and religious sentiments in recruitment and composition of the security forces in Nigeria, has had negative effects on their effectiveness at the detriment of National security and unity. Similarly, the observed neglect by the past Nigerian governments to give priority attention andrespond to the operational and administrative needs of security departments,has created inadequacies and negatively affected the combat readiness of these forces till date.It is in the light of these internal contending problems that pose security threats that this paper will examine and analyze the effectiveness or otherwise of government application of essential elements of security for the overall achievement of stability and integration of the nation as reflected in subsequent sections of this work.

\section{Statement of Research Problem:}

The several security challenges facing Nigeria is an indication of ineffective security management in the country traceable to long neglect of essential elements in security planning and management in Nigeria. There is an observed lack of prioritizing of critical elements of security by Nigeria's past leaders and political class till date which has continued to generate serious threats to its national security. The lack of adequate funding and equipping of security departments and politicization of security matters in Nigeria based on partisan, tribal and religious considerations aretraceable to the security dilemma being faced in the country till date. Lack of security awareness of the average Nigerian citizen coupled with lack of training of security personnel, also compound security problems in the country.

There are lapses in Nigeria security due to only agovernment approach towards security in all Nigeria where the country's security management is not all in-inclusive of both public and private security management elements. This paper states thatuntil these critical elements of security are given priority attention and implemented promptly, the nation will continue to grapple with crippling security challenges that threaten her security and unity in the now and in future.

Other lapsesin critical security elements application inNigerian security include; (i) inadequacies in manpower recruitment and training of security forces and law enforcement agencies (ii) lack of timely and promptness in the handling of security issues by government (iii) lack of citizens involvement in state security management(iv) low standard of security awareness (v) reluctance by citizens to volunteer security information to law enforcement agencies (vi) slow threat response by government to security advices on threat assessment and neutralization (vii) lack of effective coordination and harnessing of human material and technical resources (viii) poor funding of security agencies and low motivation of security personnel (ix) lack of effective security networking between security and law enforcement agencies (x) lack of security personnel self control and discipline. Others are; (xi) lack of secrecy and porous security network (xii) non-adherence to document security classifications and violation of oaths of secrecy Actsin security and government departments in Nigeria and (xiii) neglect and abandonment of retired security personnel who would have still been useful to the nation but are often abandoned by their former department after retirement which can force some of them to engage in criminal activities.

\section{Research Questions:}

To guide the discussions in this work, it is pertinent to ask the following questions:

- How effective has the Nigerian state utilized the essential elements of security to achieve one indivisible, egalitarian and united country, despite its pluralism and heterogeneity?

- Why has the Nigerian state not been able to orfailed to harnessher abundant critical elements of security?

- Are critical elements of security in Nigeria managed in such a way that stability and integration of Nigeria is encouraged or guaranteed?

- What are the geneses and remote causes of heightened security threats in Nigeria?

- Are these security challenges traceable to the above mentioned security lapses in Nigeria?

\section{Theoretical Framework:}

In recognition of the diverse nature of security challenges in Nigeria and the need for a holistic approach to deal with these re-occurring challenges, this paper is adopting a multi-track security model with a three-layered security management principles as key to effective security management in Nigeria. This collective security management approaches are advocated by Barry Buzan (1983) considers three-referent objects for; theindividual, national security and the international systems as referent objects for effective security management. This collective security approach is apt for Nigeria due to the multi-cultural, multi-ethnic and heterogenic nature of Nigeria which needs an all-inclusive approach to its security management. 


\section{Methodology:}

The method used in this study is descriptive. The method will help in analyzing the problemsbe-setting Nigerian state from harnessing the critical or essential elements of security in achieving the nation's stability and integration. The data for this article were collected from a range of existing primary and secondary sources, mainly textbooks, journals, published and unpublished materials. The data collected were analyzed descriptively. The justification of this method is that descriptive research is usually not limited to a single method of data collection. As Ndagi (1984) rightly notes, descriptive research is concerned with interpreting existing conditions such as prevailing practices, beliefs, attitudes, and on-going processes. In the same token, Best (1970) in Nnabugwu (2004:172), argues that descriptive research is concerned with condition or relationships that exist; practices that prevail, beliefs, points of view or attitudes that are held, processes that are going on, effect that are being felt; or trends that are developing. Further still, he contended that descriptive research "looks at individuals, groups, institutions, methods and materials in order to describe, compare, contest, classify, analyze and interpret the entities and events". However, descriptive social science research as Anikpo (1986:37), posits, strive to unravel, find out or determine the essential elements and characteristics of any phenomenon or attribute.

\section{Literature Review:}

Security like other concepts has essential or basic elements that make it what it is. Security, though a robust term is used to describe all measures taken to discover, assess and contain threats from hostile intruders. Security is also seen as all measures, precautions, actions and personnel put in place that ensure safety to lives and assets and provide a peaceful atmosphere for citizens and Government to pursue their legitimate activities without fear, threats or hindrances in a given country. It thus involves the protection of lives and property and the provision of a peaceful and tranquil atmosphere in which individuals can go about their lawful businesses (State Security Service - SSS, 2005:28).In a narrow common sense and usage, security as a concept is similar to safety. Security means that something is not only secured but has become secured (Eselbor, 2007:102). In a more general sense, security includes activities, institutions and technologies involved in the protection of a country, property or persons against attack, danger and so forth. It is these activities, institutions and technologies that constitute essential or basic elements of security. Oduneye (2008:1), perceived security as the establishment and maintenance of protective measures which are intended to ensure a state of inviolable from hostile acts or influences. It is also seen as a whole set of actions by which the government guarantees the safety of lives and property of its citizens from internal and external influences(ISECOM, 2005).

Government actions must be based on a number of factors such as human factor, resources, perception and public image of security forces, combat readiness of security forces, networking and liaison between security forces, intelligence procurement and sharing of information dimensions, among others. It is the constitutional responsibility of the Nigerian government to harness, co-ordinate human and financial resources of the nation for the protection of lives and property of her people. This brings to mind the concept of security administration. This refers to the ability of government to organize the staffing, directing, leading and controlling, effectively funding and motivation of security agencies and personnel for the provision of security for its citizens through the use of instruments and mechanism of state power backed up by enabling laws. This often involves strategies, innovations, planning, initiating solutions to solve problems through timely decisionmaking.

In Nigeria, there are several internal and external contending factors and problems that tend to tear the Nigerian nation apart, one of which is the question of security. According to Nnoli (1980), Nigerian state is made-up of different languages and multiple religious beliefs. It has different tribes with diverse traditions and cultures living under a geo-political entity, called Nigeria. Apart from other emerging state crimes that have come to stay in Nigeria and are occurring on daily basis, it is this unity-in-diversity that tends to tear-apart these diverse groups and cultures when it comes to geo-political, ethnic, tribal and economic equations during which these differences manifest in forms security and political problems in Nigeria.

Apart from these lapses, Nigeria from its inception, has suffered myriad of security problems such that, the country's stability and integration are seriously threatened. There have been re-occurrences of security challenges which have outlived solutions as no day passes without the emergence of one security challenge or the other. Presently, security situations still remain adversedue to the phenomenon of criminal violence which seem to have gone deep-rooted into Nigeria and is increasing faster with each passing day (Niger-Delta University, 2010). There are continued cases of kidnaps and hostage-takings of foreign oil companies workers by aggrieved and long-neglected youths of the Niger-Delta Region (NDR) who see kidnappings as a means of economic survival, political assassinations as well as the recent abduction of over 270 Chibok school girls in a state government secondary school in Bornu State which madeEduongo (2008:5) to maintain that, "the spate of kidnappings and related crimes are fast gaining grounds in Nigeria. Also, the various cult-related murders by rival cult groups in tertiary institutions in the country during the period gave the citizens concern as young 
students at the prime of their youth were inexplicably murdered in most tertiary institutions in the country by warring and rival cult-groups fighting for supremacy and sheer demonic urge to take human lives (Phenson, 2014).

The re-occurring problematic nature of human insecurity is of concern to all. The capacity of state actors to deliver as a statutory public policy to protect lives and property, maintain territorial integrity and other internal forms of security is becoming doubtfulin the recent timesas Nigerians have remained unprotected and unsecured despite the huge monthly allocated security votes and ever increasing expenditure on security management in Nigeria. The country has continued to suffer criminal terrorism which according to Imobighe and Equavoen (2006) relates to the use of acts of terror for private material gains, which translates itself into kidnapping people for ransoms. Due to the present security uncertainties, the Nigerian state cannot develop nor guarantee peaceful atmosphere for individuals to pursue their lawful activities. This notion Is supported byEkpe (2007) which posits that "no economic activity can take place in a chaotic atmosphere and this explains the urgent need for full application and implementation of essential elements of security to bring about the needed stability and unity in Nigeria.

\section{Objectives of Security:}

The operation of security of any nation is guided by certain principles. Therefore security as a social phenomenon is generally aimed at achieving certain aims and objectives, which include the following;

i. Security ensures the protection of lives and property of both citizens and that of government (personnel and property).

ii. To provide a tranquil and peaceful atmosphere for individuals and groups to go about their lawful engagements.

iii. To create measures and opportunity for assessment and prompt neutralization of threats and the exposure of agents of such threats to legal sanctions.

iv. Security creates a barrier and builds the walls of defense (separation) around the state and its people.

v. It builds confidence of safety, promotes peace and order and ensures safe working and residential environment.

vi. It builds a foundation (bedrock) for socio-economic and political growth, development and stability.

vii. Security minimizes panic and fear of attack.

viii. It solves societal problems, exposes criminals, their activities, hideouts, and enhances social justice.

ix. It uncovers threats and deters aggression (Bassey, 2010:8-28).

x. Security provides the enabling atmosphere for good social and political order to survive (Aja, 1999:31).

xi. Security prevents criminal activities in a society. Crime is an act which, because it affects injurious society as a whole or a member of it, infringes some law enacted to prevent such injury and thereby attracts the punishments prescribed by the law for such infringement (Sharma, 2004:102).

The importance of security cannot be over-emphasized. However, life must be secured before man thinks about how to eat, cloth and shelter himself and then proceed to talk about politics, culture and ideology. There is nothing absolute that gives meaning and essence to life except security. Security is that condition of being free from threat, stress, strains or fear of losing life and other valuables of life (Lipmann, 1974:31).

\section{Principles of Security:}

Security has its own Modus Operandi or rules of engagement or principles and they include:

1. Security Intelligence: Any plan for effective security must involve the acquisition of timely and accurate intelligence concerning the target, especially the organization, methods and motives of those that pose threat to such target.

2. Threat Assessment: This is to timely identify and access indicators of actual or potential threat areas or dangers which can impinge on security or functions of a person, place, premise or an entity. It means timely collection of intelligence and analysis of threat indicators for a better threat perception and advance planning.

3. Objectives and Aims:All security planning and operations must be based on the objectives it is meant to achieve usually national security objectives.

4. Planning: Every successful security operation is dependent upon effective planning which must go hand in hand with a number of factors, namely, economic, political, socio-cultural, legislative and legal factors/measures in that society. All planning must revolve around the objectives meant to be achieved and the security structure of that society.

5. Command and control: This is a centralized control and command structure of all security planning and operations that facilitate administration, co-ordination and gives direction in an organization. This helps rational deployment of resources and personnel and avoids duplication of resources and efforts in any 
disciplined organization. It helps to control channels of communication and chain of command from a central point to the other component units of the system as well as spells out the hierarchy of authority and issuance of order for compliance by sub-ordinates.

6. Security Liaison: For any effective security, there is need for liaison with other sister related agencies or establishments. This is absolutely necessary because effective security is a function of all and sundry in any society as postulated by Multi-Track and levels 1, 2, 3 Security Models (MTSM) propounded by Barry Buzan (1983). Close liaison (networking) with other security agencies/outfits and establishments is therefore necessary in all aspects of security operations. It is important especially in intelligence-sharing, security planning and operations. Security liaison is an inter-personal and inter-departmental interface that facilitates working relationship between two parties or between an entity and other stakeholders that often take place in advance during planning and organizing a function, or between security agencies and departments. It helps in security planning and operationsas well as advance-party arrangement to ensure hitch-free organization of operations.

7. Containment: It is not enough to discover and assess security threats or problems, the containment of such problems is important. Containment stage in every security operation is the period of enforcement of security counter- measures and this must be backed-up with necessary legal provisions and sanctions. For instance, a search operation must not be carried out without an endorsed search warrant to be signed by a Judge or Magistrate within the jurisdiction of the incident. This legal provision has been provided to backup search operations.

8. Security Re-appraisal: Security information needs to be re-appraised. All security problems are to be reexamined or re-assessed to determine the effectiveness of the desired measures in the light of new information relating to an incident or event.

\section{Critical Elements of Security:}

Essentials or critical elements of security as the name implies are those critical elements that constitute and facilitate effective security management. These include, adequate security structures and functions in a given society or environment.These include human, material and technical and spiritual elements that support security activity. It is generally categorized under three main sub-headings of; (i) Human Elements (ii) Material Elements and (iii) Technical (iv) Spiritual Elements of Security. These four categories can further be broken down in details as follows:

\section{(A) Human Essential Elements in Security Management:}

- Personal / Personnel Security Imperatives.

- Strength, quality of security man-power and its functioning pattern.

- Private and public security and law enforcement personnel.

- Citizen's level of security awareness, perceptions of security and law enforcement agencies/ departments and aspects of public relation.

- Leadership and political class perceptions and attitudes towards security matters.

- Sources and agents for procurement of critical timely information and pertinent intelligence.

- Source protection of agents and informants.

- Discipline and levels of training of security personnel.

- Access control system and security parameters of buildings and premises.

- Security and safety of materials and machineries.

- Functioning of security system.

(B) Material Elements in Security Management:

- Logistical and administrative supports to security departments.

- Security equipments availability to these security departments.

- Crime combat kits.

- Adequate and standardized government issued uniforms not purchased by these security personnel from open public markets as is the case of Nigerian security forces uniforms.

- Adequate fire-arms, ammunitions and advanced weaponry for combat readiness of these security personnel.

- Patrol vehicles availability.

- Decent office and residential accommodations.

- Health and sport facilities to keep personnel physically fit and healthy.

- Weapons training and provision of facilities for physical, academic and professionalized training for capacity building. 
- Security personnel service insurance for ensuring safety of personnel.

(C) Technical Essentials in Interior and Exterior Security Management:

These are the modern day advanced technologies like computer compliant and utilizeadvanced space age security technologies in crime combat.

- Advanced global satellite communication systems - (GSM) telecommunications gadgets.

- Advanced scientific weapon research and communication facilities.

- Sub-marine communication and military capabilities

- High caliber range fire arms, sniper long rage riffles, rapid firing guns and rocket launching missile technologies.

- Development and knowledge on explosives, landmass and bomb making and disposal technologies.

- Close circuit television/camera (CCTV) technologies. The CCTV system is used for continued surveillance of parameter fencing, isolated and vulnerable areas, loading/unloading places/locations, entry/exit gates, sensitive working places, stores/warehouses, banks, airports, railway stations, hospitals, hotels (Sharma, 2004:88). The CCTV is an effective system in industrial and corporate security. The system according to Sharma (2004:87) has been regarded as one of the most important sources in all types of security. Whether it is exterior or interior security requirement, the CCTV occupies a predominant position. It is considered to be a perfect, reliable and dependable security source which can provide real time information about all events and actions taking place at any time. Sharma (2004), further posits that "it is capable of displaying a complete picture of the area under surveillance on a monitor located in the control room. The CCTV is meant for providing audio and video information from a particular location through a close circuit".

- Audio and video surveillance and monitoring sensors.

- Cyber space and computer based security gadgetries to check global money laundering and financial crime rackets.

- Forensic laboratory facilities and advanced photographic technologies, especially for crime science analysis.

- Satellite space technologies for remote sensor monitoring and imagery used to monitor deep sea and space - based security communication intercepts.

- Advanced espionage development capabilities and gadgets for both security and industrial espionage activities.

- Computer based training for all security and law enforcement personnel to prepare them for modern day advanced security and intelligence operations and to be combat ready for modern day threats of espionage, subversion, sabotage and terrorism as is being perpetuated by the Boko Haram terrorists in Nigeria in recent times.

- Other modern devices in security system.

- Personnel explosive indicators.

- Conventional alarm systems.

- Door metal detectors.

(D) Spiritual Elements in Security Management:

There are emerging modern trend in security management and perception which is considered as the spiritual elements in managing security problems particularly in third world countries of the world. This is the seeking of divine interventions of God, the Supreme Being in solving internecine security challenges or protracted security threats. This is exemplified in Nigeria over the yet-to-be resolved abduction of over 270 Chibok's School Girls in Bornu State of Nigeria since April, 2014.

This has forced the Nigerian state and government to resort to spiritual intervention through routine nationally organized prayer for God's intervention not only for the rescue of the abducted school girls, but also, for divine intervention in solving the protracted Boko Haram Terrorist Insurgency that has continued to threaten Nigeria's security and stability in recent times.

The other spiritual element in security management is the issue of killings or threats done in the name of God such as the Muslim fundamentalists, who carryout jihadist violent acts in the name of Allah or Christian crusaders, who also kill in effort of Christian evangelism in the name of God. These prolonged security challenges have led nation states like Nigeria and individuals to engage in solemn prayer assemblies to seek God's divine interventions through prayers as a method of solving security problems that seems to overwhelm human faculties.

This new dimension of seeking divine intervention as a security approach is based on the adage, that the super-natural controls the natural and therefore, God's intervention will help provide spiritual guidance in 
solving human security problems if we seek divine interventions in any given problem or situation. This is being done by the Nigerian state which has resorted in routine prayers or to divine intermediary by God in solving her Boko Haram insurgency and its attendant security challenges in recent times.

\section{Problems of Security Management arising from neglect of Element of Security in Nigeria:}

The main critical elements of security in any country include, the defense forces for external security functions, security intelligence and law enforcement agencies and others such as; Non-Governmental Organizations (NGOs), Community Based Organizations (CBOs), Civil Societies Organization, Customs, Immigration, Prisons as well as Public, Private and Non-Governmental Actors. However, these agencies are handicapped, hence, poor execution of security responsibilities. This sub-head therefore identifies problems militating against effective performances of these security providersarising from neglect of applyingcritical elements of security in Nigeria. Some of these problems in Nigeria include, but not limited to the following thatNigeria is made up of over two hundred and fifty ethnic groups with diverse cultures, languages and religious groups and are located in different geo-political regions with different primordial and tribal attachments, but politically wielded into thirty-six states and a Federal Capital Territory, Abuja at the centre which create internal contending problems as listed below:

i. Ethnic and Tribal Sentiments:Above picture presents unity-in-diversity and portends difficulties in agreement on questions of socio-economic and political equations when it comes to allocation of limited national resources due mainly to above mentioned diversities based on ethnic considerations and sentiments. These entrenched ethnic and tribal considerations tend to influence and negatively affect performance and effectiveness of security strategies and neutralizes security forces during national emergencies. The most obvious is the human element as an essential of security management imperative in the nation's security policies. The security management in Nigeria has remained ineffective due to poor security awareness of the average Nigerian citizen who see security management as solely a government responsibility.

ii. Lack of Public Security Awareness:This is even affecting personal security consciousness amongst Nigerians as Nigerians do not display personal self control and discipline required for a security conscious citizenry especially, when it comes to official secrecy even in their private lifestyles and conducts in public. Human content, security awareness and consciousness of citizens can galvanize unity and enhance nation's stability and integration.

iii. Bad Attitude of Security Personnel to the Public:The military and security personnel highhandedness and attitude towards the citizens have continued to generate bad-public image of the personnel of these security departments which makes the public reluctant to divulge critical security information that can help better security management and prompt responses towards national emergencies. This in turn will affect public relationship between the public and security agencies which form of security communication that should normally be interactional or interpersonally oriented. Interactional or inter-personal oral communication involves not only coming into each other copresence, but that each interacting entity establishes both mental and metaphysical contact, becomes mutually responsive to each other and finally establishes a shared awareness and understanding of a common, even if mutually unbeneficial goal purpose (Umanah, 1996:5-6). For communication to take place between human beings in any given context, the interacting entities must begin to share a focus, actively attend to each other's behavior and public acts, and begin to reciprocate such actions and behavior. Each party must take others into account by actively attending to their interacting selves. When this happens, according to Umanah (1996:2), they move towards or become involved in the exchange of meaning information. This makes communication the process of transmitting mutually understandable and meaningful message information between two or more interacting entities. In our case, the transmission of mutually understandable and meaningful information to security and law enforcement agencies to aid them in the day to day detection of criminals has become a major task. The fear is that information so given will be divulged with attendant dangerous consequences on the part of the public. Poor public image of security forces often affect the willingness of members of the public to divulge security information to security and law enforcement agencies. Where there is poor public image of security and law enforcement agents, the citizens remain reluctant to volunteer valuable security information which negatively affects stability and integration of the nation (Phenson, 2014).

iv. Militarization Policy in a Democratic Dispensation: The militarization of Nigerian security management terrain even in the current democratic dispensation has reduced the Nigerian police force to a mere-on-looker in internal security management of Nigeria. The above assertion is true more due to poor government funding and equipping of the Nigerian Police Force by past military regimes in 
Nigeria. The long military rule and continued use of the military in security management in Nigeria though, has contributed in containing domestic crisis situation beyond police capabilities is still seen as a misnomer in a democratic dispensation. Also, the continued presence of military personnel in the oil producing Niger-Delta region has been counter productive, where their presence in the region, forced the ironically un-employed youths from the oil rich region, to resort in self defense to arms struggle and reprisal attacks in retaliation of the brutal and punitive military operations against the genuine protests for development of the long neglected, oil producing region, at the detriment of national peace and security in the region till date (Phenson, 2014). Problem of militarization of Nigerian security by military personnel in a democracy, tend to develop culture of military brute force, and at the expense of public trust and image.

v. Insensitivity of Nigerian Government Officials and Political Class towards Security Matters in Nigeria: The attitude of Nigerian leadership and political class towards security matters in Nigeria has been that of paying lip-services to security departments and adopting on retroactive, fire-brigade approach instead of proactive and offensive security intelligence and timely security responses to national security issues. It is this observed human element amongst Nigerian political class and general apathy of average Nigerian lack of security consciousness, that has thrown Nigeria into a situation where ethnic militias hold sway as OPC operating in the Western region, MASSOB and Niger-Delta militants in the South and Eastern regions and Boko Haram terrorists detecting security management pattern in the country at the detriment of national security and cohesion in the country. However, principle of political direction should be applied in the security administration. This states that public administration being an agency of the state is subordinate to the political executive. This according to Ekwealor (2007:51), ensures that administration is kept separate from politics. In the like manner, security should be kept separate from politics.

vi. Inadequate Manpower in Security Departments: There is an observed shortages and inadequacies amongst the Nigerian security departments and these personnel lack proper funding and motivations which negatively affect their performances and invariably impugn on the national security management capabilities.

vii. Lack of Training of Security Personnel: There is no security department above issue is most prominent than the Nigerian Police Force whose personnel are known for official corruption arising from prolonged government neglect for adequately funding and equipping the Nigerian Police Force. Other security departments such as Customs, Prisons and Immigration Department have not faired better as these security department suffer from inadequate funding by Nigerian government except in recent times, due to resurgence in crimes and increased domestic threats arising from ethnic militias that is threatening national cohesion and unity of the country. As a function of effective management, security staff or personnel should be properly organized and directed, adequately budgeted for and security departments well staffed. Staffing according to Ekwealor (2007:7-8), is the process by which managers select, train, promote and retire personnel. Lack of training in modern crime combat strategies and obsolete equipments to fight crime particularly, in the Nigerian Police Force.

viii. Lack of Discipline amongst Nigerian Citizens and Security Forces: One of the greatest human essentials of security is lack of discipline amongst Nigerian citizens and security forces. The government workers no longer observe official secret Acts laws, the security personnel are engaged in corrupt practices and extort money from citizens at the expense of national security especially, the police personnel and border controls security officials who allow influx of smuggled good, importation of dangerous and illegal fire-arms and above all, influx of terrorists and imported aliens into Nigeria at the detriment of national security due mainly to their human greed and monetary gains.

ix. Lack of Effective Liaison/Espirit de Corps:There is no sufficient team spirit and collaboration between the Nigerian security forces and law enforcement agencies. Harmony and union help to build the strength of security departments. This work believes that if there is harmony and unity between security personnel and agencies across the country and their managers, or heads of security departments showed serious concern for employees (human elements), increase productivity would result. Thus, security is a collective responsibility. Security management is not a mere servant or an agent for carrying out or implementing orders whose absence or neglect means doom, anarchy, etc. The complexities of social action are so great that security institutions alone cannot cope with their execution. Much therefore has to be left to the law abiding citizens who should work co-operatively with security agencies and forces if national security objectives are to be attained. For national security objectives to be realized, the role and feeling of the public must be appreciated. The principle of research which entails the introduction of new methods, techniques and plans should be in security management. The flows of information and intelligence sharing between departments enhance the capacity to contain security challenges that ensures stability of a nation. 
x. Level of Technological Advancement: The level of technological advancement both for military and security intelligence services help in capacity building that goes a long way to enhance stability in a nation. For example, the USA with her advance technologies hashelp her global capabilities to procure intelligence and maintain her security at home and abroad.

xi. Poor Equipments, Motivations and Quality of Morale Factors: Poor equipment and motivations of security forces often negatively affect security performance and effectiveness of security forces to combat destabilizing and subversive activities in a nation.

The quality and morale boosting factors often help the effectiveness of security forces and enhance their combat readiness to tackle security challenges that bring about stability in a nation like Nigeria. The low morale and inadequate motivation and welfare packages to these security personnel tend to demoralize the security operatives and negatively affect their performances. These security outfits lack basic equipments and are technically-outmoded in terms of modern crime fighting technologies, especially the Nigerian Police. The Nigerian Police lack fire-power, forensic laboratories, modern communication and technical equipments for professionalized police duties as obtained in civilized countries abroad.

xii. The Level of Computer Compliance: The level of computer compliance and applications of (ICT) Technologies in the operations and planning of military and security duties, can help ensure prompt responses to security emergencies and enhance stability in a country.

xiii. Quality of Law Enforcement Agencies \& Level of Logistical Support:The qualities of law enforcement agencies and their level of equipment and logistical supports go ahead to enhance their morale and boost their performances that help maintain stability in a country. This will boost the capacities of the military forces and security intelligence services that help in maintaining foreign relations international security commitments and treaties signed on behalf of Nigeria. E.g. ECOMOG security and peace-keeping missions in West Africa and other parts of the world by Nigerian military and police personnel. The security and military forces help in maintaining security and stability in Nigeria by containment of internal subversive elements and insurgencies that help the stability of Nigeria. The training academies for military and security intelligence services help in training, retraining of military and intelligence manpower for security matters and crime combat in the polity. The military and security forces help in monitoring of border controls to check influx of illegal aliens, illegal smuggling of arms, ammunitions and contraband goods and other across the border crimes in Nigeria. Currently, the military and security forces, help in checking crude oil thefts in the Niger-Delta region, monitor the activities of Niger-Delta militants and help in controlling oil pipeline vandalism and sundry crimes in the region through the Joint Military Task Force. The military and security intelligence services help also in checking espionage and terrorist's activities that can destabilize the country.

xiv. Poor Funding of Security Operations: Poor funding of these security have outfits that are presently battling with rag-tag Boko Haram Terrorists with only little or qualified successes.

xv. Corruption in Nigeria: The problem of corruption amongst security forces and their high handedness gives them bad public image and indirectly, affects public trust and reluctance to divulge security information to these brutish and highly corrupt security personnel in Nigeria.

xvi. Over-Centralized Command and control of Security: The over-centralized command and control of the Nigerian Police and other internal security providers in the country does not make room for rapid response at state levels and invariably, affect their performance and responses in emergences.

xvii. Insensitivity to Security Problems: The insensitivity of political leadership in Nigeria to security matters tends to becloud performances of these security delivering outfits. Rather, it is observed that political class, instead of properly funding these security forces tends to misuse them for selfish private protection purpose at the detriment of national security.

xviii. Bad Leadership and Governance: Bad leadership and bad governance in Nigeria also tend to alienate the public from divulging intelligence to security forces and makes the public reluctant to assist government in issues of prompt security management.

xix. Sentiments: Geo-political, religious and tribal sentiments tend to influence security matters as politicians now tend towards politicizing security personnel and turn them from their statutory functions at the expense of national security.

\section{Geo-political and Security ProblemsAffecting Stability of the Nigerian State:}

- Geo-political Position of the Nigerian State: The geographical location of Nigeria predisposes it to hostile and at times, jealous neighbouring countries of Cameroons, Chad, Niger, Benin and Equatorial Guinea from where subversive terrorists and hostile intelligence agents infiltrate into the porous Nigerian borders to cause harm and terrorism in Nigeria. 
- Porous Nigerian Borders: This tend to encourage smuggling of contraband goods and influx of un authorized aliens, illegal arms, weapons and ammunitions and other cross-border criminal activities which are infiltrated easily in the country and used to cause instabilities in Nigeria.

- Ethnic and Religious Intolerance: These twin demons have remained the bane of continued instabilities in Nigeria as these two issues tend to tear apart various ethnic groups, tribes and different religious faith believers apart and create deep dividing cleavages that cause instabilities in Nigeria.

- Over Population: The large Nigerian population and the uncontrolled increases in our population without corresponding planning and internal housing and industrial capacity building to gainfully employ have affected the nation's growth.These ever-rising populations are presently and potentially a security threat to the country.

- Un-employment and Poverty: A major security challenge confronting the Nigerian state now is the twin plaques of un-employment and its accompanying sister, poverty. The two problems are joint products of lack of internal capacity building by the Nigerian state and they both represent security challenges that produce instabilities in Nigeria.

- Corruption in Nigeria: This problem has eaten deep into segments of the Nigerian polity and has remained intractable to control. It is hoped that it does not infiltrate so much into the armed forces and security agencies as feared in recent times where it may cause serious security and stability problems in the country. Vito Tanzi cited in Igwe (2010:107) defines corruption as the intentional non-compliance with the arm'slength principle aimed at deriving some advantage for oneself or for related individuals from this behavior. An alternative definition of corruption frequently used by the World Bank specifies corruption as "the abuse of public office for private gains". However, there are straight forward thefts, fraud, embezzlement or activities similar to corruption. Corruption finds root and easily becomes embedded where political leaders fails to display concern for the public interest or fail to set examples of integrity, where social and political institutions are relatively weak, and where civil servants often unpaid and held in low public esteem. It also flourishes when the public is poorly informed, apathetic, cynical, tolerant or so weak to be unable to protest. In Nigeria for instance, much of the large-scale corruption has involved politicians themselves and senior bureaucrats who are part and parcel of the governments in power (Igwe, 2010:140).

- Politically-Motivated Threats: These are security challenges that arise from election-related and politically-motivated challenges that cause instabilities and crisis in the Nation-Nigeria. Such challenges include, election related violence, kidnappings, election riggings and mal-practices, politically-motivated assassinations of real or perceived political opponents, political thuggery, illegal-arms to enforce their political wishes which are left in checked after elections in the hands of thugs. These illegal arms are after elections used by these thugs to wreck havoc in the polity at the detriment of peace and stability in the country (Phenson, 2010).

- Socio-cultural vices: These are criminal activities that arise from misuse of drugs, prostitutions, illegal misuse of fire-arms for arm robberies, kidnaps, hostage takings for ransom, child trafficking, cultism and cult-related wars of supremacy with attendant loss of lives by rival cult groups.

- Economic Dependency Problems: The dependency of Nigeria on mainly oil exports has led to a monocultural economy and dependency. Without diversification of our economy, the accompanying low internal capacity-building cannot generate job opportunities which worsen unemployment and generates army of unemployed, plagued by poverty and ready for any impulse to commit crime as a means of economic survival. Some of these unemployed youths now graduate into cults and robbery gangs, terror groups, crude oil thefts and oil pipeline vandalism especially in the Niger-Delta region, as political (OPC) thugs in the West, and Boko Haram Terrorists sympathizers in the Northern part of Nigeria. All these contending challenges not only tend to destabilize Nigeria, but, are veritable grounds for future revolution in the country if they are not promptly tackled holistically to ensure continued unity, stability and security of the nation by adopting a multi-dimensional security approaches to be discussed in the course of this paper.

- Politicking with Security Essentials in Nigeria: The misuse of security personnel and playing politics with security matters at high government decision making positions, has had serious consequences on Nigerian state capacity and promptness in containing instabilities or crises in Nigeria. This stems from sentiments that border on partisan political considerations, religio-tribal sentiments and geo-political consideration that not only delay decisions, but negatively affect the prompt responses expected from the Nigerian government during national emergencies. This is exemplified by the delayed response to the Boko Haram Insurgency until they struck and seize the Chibok Secondary School Girls, who are still detained by these inglorious terrorists in the face of all Nigerian Departments who lack the capacity to fight terrorist operations.

- Threat to National Cohesion and Unity: A major consequence and observed neglect of security essentials in Nigeria, is the continued threat to her corporate existence and unity. The inability of the nation's security outfits to manage security problems due to a inadequacies, have increased ethnic and geo-politically- 
motivated tensions that tends to pull the nation apart and could lead to its disintegration if not properly and promptly tackled. This is true in the fact of the current threats to Nigerian unity arising from pockets of insurrections that arose from ethnic militias spread across geo-political zones of Nigeria. For example, Odua People's Congress (OPC) in the West,Movement for theActualization of Sovereign State of Biafra (MASSOP) to the Eastern Zone and the current Boko Haram insurgencies, terrorizing the Northern region of Nigeria. All these internal subversive and ethnic motivated security challenges have continued to destabilize the Nigerian state with repercussions on her fragile unity.

\section{Discussions:}

The perennial security challenges in Nigeria seem to come from different sources and these have longdrawn consequences on effectiveness of stability and integration in Nigeria. A look at the various security problems incubating the stability of the Nigerian state will reveal that the country is currently faced by problems that cut across social, economic, religions, ethnic, tribal and geo-political factors that need to be addressed urgently for peace and stability in the country. The concept of security management deals with the organizing, planning, controlling, directing and integration of technical, human, material, intelligence and security resources towards achieving security goals and objectives. It involves system's security management and coordination, planning efforts with other departments, working and net-working simultaneously with others to achieve collective security goals and objectives. In the case of Nigerian state, these will be collective efforts by all defense and security forces, other law enforcement institutions including state and non-governmental organizations as well as private security efforts that go on to ensure peaceful co-existence of federating units of Nigerian state and its stability. These sectors should contribute meaningfully in securing the Nigerian. The work has identified what have been militating against effective security management in the country.

Some of these lapses and attendant negative effects on Nigerian security management are attributable to:

- The poor-funding of security departments in Nigeria by the Nigerian Government. This is manifested in lack of patrol vehicles, poor equipments of security departments in the country. These inadequacies tend to have negative consequences on the performances and combat readiness of these security forces in Nigeria.

- Lack of welfare and motivational packages such as poor salaries, lack of life insurance cover, non-supplies of uniforms and health care facilities for these security departments. These are seen by this paper as responsible for the observable low morale and low self-esteem prevalent amongst the security personnel especially, the junior rank and cadre in these security departments.

- The lack of barrack residential accommodation and administrative offices tend to subject the personnel of these security departments to living and squatting under inhuman conditions. Some are forced to live amongst the society and public which predisposes them to insecurity and public ridicule during their journeys to and fro, work or offices. The lacks of these essentials tend to have negative effects on professional conducts and performances of these security departments in Nigeria.

- The bad-public image and poor security public relations tend to negatively affect their performance and relations with the public who are often, reluctant to divulge security information to these security personnel seen as enemies to the public, especially, the Nigerian Police Personnel.

- Obsolete security communication systems and poor technological advancement in the security departments of Nigeria. The new age of (ICT) compliance and computer technologies in the global communication system is still lacking and inadequate in these security departments of Nigeria. This obsolete technical status of Nigerian security has far-reaching consequences on their professional-combat readiness and negatively affects their performances.

- The endemic and virulent corruption has eaten deep into the ranks and files of Nigerian security departments and has continued to create bad public-image of these security forces in Nigeria. This can be traced to insensitivity of the Nigerian government official who are supposed to equip, kit and adequately motivate security agents who are forced to resort to taking bribes and engaging in corrupt criminal activities as a means of economic survival.

The United Nations standards and ratio of policemen per citizen is put at about 222 per 100,000 people. However, this is not the case in Nigeria and some other African countries where the number of police per citizens in Nigeria is far below world's acceptable standard for effective policing in the country. The low ratio of police per citizen has continued to negatively affect security management in Nigeria with attendant consequences on the capacity and professional capabilities of the Nigerian police personnel to adequately combat crime and check instabilities in Nigeria. This is reflected in the table below indicating police citizen ratios for some selected countries of the world, including Nigeria. Nigeria as indicated in the table below is ranked $66^{\text {th }}$ in the United Nation Organization (UNO) police-citizen ration with a ratio of 205 policemen guarding 100,000 citizens on the average as shown below. 
Some Selected Countries with Low-Police/Citizen's Ratio:

\begin{tabular}{|c|c|c|c|c|c|}
\hline $\mathbf{S} / \mathbf{N}$ & NAME OF COUNTRY & $\begin{array}{c}\text { SIZE PER SQUARE } \\
\text { MIL. }\end{array}$ & $\begin{array}{c}\text { POLICE-CITIZEN } \\
\text { RATIO }\end{array}$ & $\begin{array}{l}\text { YEAR OF } \\
\text { RECORD }\end{array}$ & $\begin{array}{c}\text { LEVEL OF } \\
\text { COMPLIANCE }\end{array}$ \\
\hline 1. & Mali & 7,000 & 48 & 2012 & Very Low \\
\hline 2. & Niger & 8,700 & 58 & 2012 & Very Low \\
\hline 3. & Comoros & 500 & 66 & 2012 & Very Low \\
\hline 4. & Togo & 4,000 & 72 & 2012 & Very Low \\
\hline 5. & Iran & 60,000 & 80 & 2012 & Very Low \\
\hline 6. & Kenya & 35,000 & 81 & 2012 & Very Low \\
\hline 7. & French Polynesia & 220 & 82 & 2012 & Very Low \\
\hline 8. & Bangladesh & 135,000 & 83 & 2012 & Very Low \\
\hline 9. & Ghana & 23,000 & 94 & 2012 & Very Low \\
\hline 10. & Guinea & 10,000 & 100 & 2012 & Very Low \\
\hline 11. & Papua New Guinea & 5,311 & 105 & 2012 & Very Low \\
\hline 12. & New Caledonia & 268 & 106 & 2012 & Very Low \\
\hline 13. & Liberia & 4,100 & 108 & 2012 & Very Low \\
\hline 14. & Lesotho & 2,404 & 116 & 2012 & Very Low \\
\hline 15. & Haiti & 12,000 & 118 & 2012 & Very Low \\
\hline 16. & China & $1,600,000$ & 120 & 2012 & Very Low \\
\hline 17. & Wallis \& Futuna & 20 & 136 & 2012 & Very Low \\
\hline 18. & Finland & 7,800 & 143 & 2012 & Very Low \\
\hline 19. & Somalia & 35,000 & 198 & 2012 & Very Low \\
\hline 20. & Nigeria & 350,000 & 205 & 2012 & Very Low \\
\hline
\end{tabular}

Source: United Nation's Report, 2012.

The High Crime Incidence in Nigeriais an off-shoot of negligence by Nigerian government to properly fund and harness the essentials of security in combating instabilities in Nigerian. This has made room for criminals to operate with impunity as they have higher firing power and sophisticated weapons than the government security forces. This is evident in the current war against Boko Haram Terrorists, who are visibly more equipped with weapons and bombs of mass destruction which the Nigerian security forces are presently, finding it difficult to contain with adverse effects on stability in the nation. The security of any nation depends on its effective controls against external aggression and containments of its internal instabilities. A country like Nigeria, with porous border control systems made up of inadequately equipped border security personnel, faces influx of illegal aliens, unchecked influx of illegal arms and weapons as well as smuggling of contraband goods and other cross-border crimes. These illegal activities across the Nigerian borders have continued to have negative effects on how best Nigeria can contain instabilities and her capacity to manage crisis in the country.

\section{A. Human Essential Elements Applicationin Security Management:}

Some of the observable deficiencies in effective security management include the following;

- Lack of security awareness amongst Nigerian citizens.

- Bad attitude and perception of Nigerian government officials to security matters and threats.

- Wrong attitude of security personnel in Nigerian towards the citizens.

- Reluctance of Nigerian citizens to give useful security information on time to securityagencies.

- Politicization of security departments by political class in Nigeria.

- Corruption amongst these security personnel and amongst Nigerian citizens.

These paper views the above short comings that arise from human weaknesses and human nature as impediments to effective security management which tend to affect the stability of Nigeria. It is the view of this paper that if the government of Nigeria can properly fund and motivate the security personnel through adequate remuneration, good salaries, proper residential and office accommodation, adequate equipments and motivation through welfare packages, the issue of corruption and attitudinal changes from security personnel to citizens and vice-versa, will help in effective administration of security management in Nigeria particularly in the area of giving information willingly by the public to security forces.

Similarly, if the government officials will properly address these human essentials of security, the nation's security management will become effective and her stability ensured.

\section{B. Material Essential ElementsApplication in Security Management:}

The protracted struggles by the Nigerian military and security forces to defeat the Boko Haram insurgency is an indication of the non-combat readiness of herdefense and security force before the advent of these terrorists insurgency in Nigeria. This is where material and logistic support deficiencies of these security department have been much evident and especially, in the Nigerian Police Force where the government poor funding and equipping of the police force have been contributing to the poor performances of police personnel over the years. 
The role of modern technological gadgets and necessity of operational and administrative equipment for these forces in the face of rising security challenges in Nigeria cannot be over-emphasized. A look at the average Nigerian police personnel shows that the force is inadequately equipped for modern day crime combat as the force still suffer from lack of operational equipments ranging from lack of communication gadgets, patrol vehicles and equipped forensic labouratories. The worse still is the lack of government provided official uniforms, kits, limited fire-power, obsolete operational equipment and lack of office and residential barracks accommodations.These inadequacies make the Nigerian Police Force to depend on assistance from some wealthy politicians who turn around to misuse these security personnel during elections, against their political opponents or force these security personnel to compromise their statutory functions at the detriment of national security objectives or their professional duties.

It is hoped that if these security departments and the Nigerian military are well funded and equipped as is the case during foreign peace-keeping missions where the United Nations fund and well equipped theseNigerian security forces, they will invariably perform betterthen at home and abroad where they have often excelled to the amazement of international community. The use of well-equipped forensic labouratories for the police force will help the police force to fight crime and investigate promptly on-the-scene crimes and if well funded and equipped,these defense and security forces will perform better and be combat ready for modern day crime combat any time, any where duty calls in Nigeria and abroad.

\section{Technical Essential Elements Application in Security Management:}

The use of modern day high technologies in fighting and proactive monitoring of criminal activities cannot be over-emphasized as criminals develop in their devices, the security forces, also, should update their modus operandi, in crime fighting methodologies. The need for utilization of modern day space satellite technologies in communication and use of computerize crime monitoring gadgets is indispensable in present day crime combat strategies. Technological advancement in weapon development is expected to give the Nigerian security forces, firing power advantage over criminals who's sophisticated weapons, seems presently to be superior to that of Nigerian military and police personnel.

\section{Conclusion:}

It is the finding of this paper that thesecurity departments in Nigeria are not well funded or equipped with up-to-date equipments to be combat ready in terms of modern day crime fight which iscontributing to destabilizing factors traceable to neglect of essential elements in security management system in Nigeria. Some of these factors include; geo-political position of Nigeria with long and porous borders which permits influx of illegal weapons, illegal aliens and across-border criminal activities like smuggling and importation of terrorists and imported revolution.

The heterogeneous nature of diverse ethnic and religious groups in Nigeria makes it difficult for an effective centralist security system to work. This is traced to ethno-religious; tribal attachments and sentiments that tend to distort collective decisions during security emergencies and often delay responses by government during national emergencies.

This paper concludes that security departments in Nigeria need to be adequately funded, motivated and mobilized with appropriate and modern equipment and should be given hi-tech communication gadgets and high-caliber weapons, to enhance their combat readiness to enable them cope with current security challenges in the country including the current Boko Haram terrorist insurgency and other domestic subversive activities in Nigeria.

\section{The Way Forward:}

This paper recommends a total over-haul and re-training of security forces in modern technologies for combat readiness, especially the police force which lacks modern crime-fighting equipment and are poorly paid making them suffer from low morale whichnegatively affect their performance towards national security safeguards and objectives. It is suggested that a collective security strategies in security management(a three layeredsecurity management model)which has holistic and all-hazards approach in it'splanningand operations to be introduced and effectively implemented.

In a multi-cultural and multi-ethnic country like Nigeria, with divergent security challenges which often to pull these tribes apart, this paper suggests a security management strategy based on complex interdependence as a balance of power approach to accommodate the various interests of diverse ethno-geo-political groups that make-up Nigeria.This will ensure mutual respect and collective defense of Nigeria by all federating units in the event of aggression from one segment of the country as was the case during the Eastern Region (Biafra) rebellion where other parts of Nigeria rose up in oneness and defended the country against the Biafra rebellion or secession between 1967-1970. 
The government should ensure proper funding, insure the lives of security personnel and equipthese security agencies and pay them well to enhance their performance and combat ready in the face of rising security challenges in Nigeria.

It is the advice of this paper that the Nigerian government need to not only adequately fund her military and security forces, but to pay them well, provide office and residential accommodation, issue free official uniforms especially to the police personnel, and adequately motivate and fund their operations, to improve their performance and enhance their combat readiness in the face of heightened security in Nigeria.

It is advised that the Nigerian Police Command structure be de-centralized for prompt response to emergencies at state and local levels, as well as introduction of effective community policing and public private partnership security managementapproach for grass-root crime combat.

Government should use conscious, rational and deliberate effort to co-ordinate, mobilize security group activities, combining and harmonizing efforts to achieve both internal and external security objectives. This should be application of prudent behavior based on rational principles to direct, co-ordinate, control, motivate and channel the collective efforts of citizens, (human, materials technical resources and spiritual) for the accomplishment of the objectives of national security.

However, it is heart warning to hear that the Nigerian Government has decided to revitalize the Nigerian policy reform programme under President Good luckJonathan and it is envisaged that the Police Force and other security agencies, will be well equipped and made combat ready for modern day crime fight.

\section{References}

[1]. Akpuru-Aja, A. (1999). Policy \& Strategic Studies. Nigeria: Willyrose\& Appleseed Publishing Company.

[2]. Anikpo, M. (1986). Foundation of Social Science Research: A Methodological Guide for Students. Enugu: Abic Publishers.

[3]. Ayoade, J. (1985). Political Behaviour. The Nigerian Journal of Economics and Social studies pp. 21-27.

[4]. Buzan, B. (2006). National Security, A New Radical Perspective, SNAAP. Press Msara.

[5]. D. Frisch, (1994). Effects of Corruption on Development in Corruption, Democracy and Human Rights in West Africa. Cotonou: Africa Leadership Forum.

[6]. Ekwealor, E. (2007). Fundamentals of Public Administration. Onitsha: Abbot Books Ltd.

[7]. Eminue, O. (2003). Introduction to Political Science (CATS) Publishers, Calabar, Nigeria

[8]. Heather, T. (2002). Alternatives: Shippery Security; National and Global Security Issues. Turkish Journal of International Relation. Vol. 1 No 4 winter 2002 pp 109-112.

[9]. Igwe, C. (2010). How Africa Underdeveloped Africa. Nigeria: Professional Printers \& Publishers.

[10]. Imobighe, T. and Equavoen, A. (2006). Terrorism and Counter - Terrorism: An African Perspective. Nigeria: Heinemann Educational Books, Plc.

[11]. Institute of Security and Open Methodologies, USA (2005).

[12]. Kegley, C. (2006). World Politics: Trends and Transformation: Conceptualization of a State. USA, University of South Carolina.

[13]. Ndagi, O. (1984). Essentials of Research Methodology for Nigerian Education. Ibadan: Ibadan University Press.

[14]. Nmerole, C. (2008). Police Interrogation in Criminal Investigation (Historical, Legal \& Comparative Analysis). Minna: Halygraph Nig. Ltd.

[15]. Nnabugwu, M. (2004). Fundamentals of Political Inquiry. Nigeria: Quintagon Publishers.

[16]. Nnoli, O. (2003). Ethnic Politics. $4^{\text {th }}$ Dimension Press Enugu, Nigeria.

[17]. Nnoli, O. (2003). Introduction to Politics. Enugu: PACREP.

[18]. Sharma, R. (2004). Industrial Security Management. New Delhi: New Age International (P) Publishers Limited.

[19]. Umanah, A. (1996). Human Transactions: Communication for Power, Productivity and Profit. Uyo: Dorand Publishers.

[20]. World Bank, (1997). World Development Report. New York: University Press. Chapter 6. 